\title{
Dwa polskie teksty ,ku przyzbrojeniu wojownikowi chrześcijańskiemu” z pierwszej połowy XVII wieku
}

Mirosław Lenart 


\section{Dwa polskie teksty ,ku przyzbrojeniu wojownikowi chrześcijańskiemu” z pierwszej połowy XVII wieku}

[Żohnicrz] się tego na wojnic nanczył, i wzór i pobudkę z wojny widomej do nicwidomej brać umie. (Piotr Skarga, Żotnierskie naboźnistuo)

W Jjęte tu zdanie z modlitewnika przeznaczonego dla wojska przywodzi na myśl przede wszystkim kontekst historyczny gnębionej wojnami i niepokojami spolecznymi Polski początku XVII wieku oraz naktadającą się na to atmosferę kontrreformacji. W czasach gdy sprawy Polski zdawaly się interesować samo nicbo, o czyn przypominal w drugiej połowie stulecia Piotr Jacek Pruszcz w swoim Morzu taski Bozoj (Kraków 1662), przywolując widzenie pewnego franciszkanina w Rzymie, związane ze zwycięstwem nad Rokoszanami pod Guzowem', droga przez życie przeciętnego człowicka przybierała obraz walki nie tylko fizycznej, ale i duchowej z siłami zta. Początek wicku obfitował w edycje modlitewników dla wojskil. z których jeden z trzech wydanych przez. Franciszka Cezaregow 1618 roku typograf zadedy-

\footnotetext{
'Pruszcz. powolując siç na Albrychta Stanisława Radziwilla (ksiçcia na Otyce i Nicśsiciczu). zannieszeza opo-

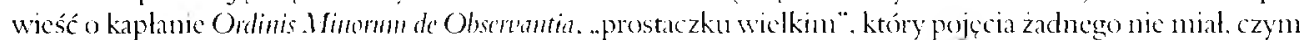
jest Polska, i który podezas Mszy św. odprawiancj we Rzynic takic mial widzenie: .tego waśnic dnia kérego

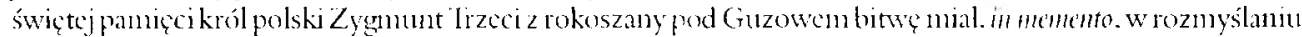

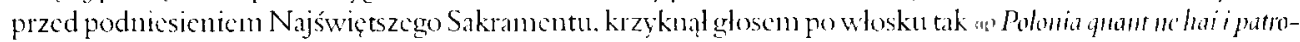
ni'm: po polsku tak siç man rozumicć: «o Polsko, jak ty masz wick obrońców!n. Spytany po misze świçtcj. dlaczego się tak glośno ozwal, odpowiedzial posluszeristwem związany. iz widziat. a ono dekret Bóg wydal na jakas

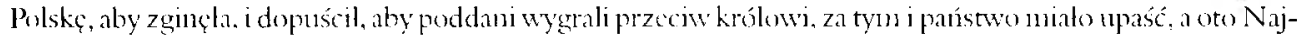
świçtsza Panna, powstawszy: padta na oblicze swe przed Majestaten Bożym. a za jej powodem i patronowic polscy upadli, prosząc o odmianç dekretu i haskaw'szą sentencją. Uczynil lan Bóg. o co prosili: pod ten czas, i tego dnia król bitwę wygral. jako się z relacjej prawdziwej doznalo: Non in multitudinc exerims riotoria betli, sed

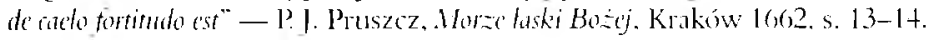


kowat samemu Zebrzydowskiemu, o czym warto wspomnié w kontekście tematu konferencji ${ }^{2}$. Spośród wydawnictw tycl uwagę zwracają dwa rzadkie dzieła podejmujące zagadnienie rynsztunku duchowego, których autorami byli: nieznany bliżej Stanislaw Kolakowski lub Kulakowski oraz zasłuzony kapelan wojska, dominikanin Szymon Okolski.

Jednym z najczęściej eksploatowanych motywów malarskich związanych z osobą św. Pawła jest jego upadek z konia w trakcie podróży do Damaszku, będący początkıem nawrócenia. W przedstawieniach, zwłaszcza XVII-wiecznych, widać rycerza we wspanialym pancerzu z tarczą, którą osłania się od bijącego z nieba blasku, nie mogąc jednak za pomocą tego uzbrojenia powstrzymać mocy, z którą przychodzi mu się zmierzyć. Przedstawienie to przypomina o tym, że początkowo wlaśnie Paweł prześladowal chrzéścijan „z micczem w ręku”, a od momentu swego nawrócenia zamienil wcześniejszy oręż na miecz słowa Bożego. Teksty na temat duchowego rynsztunku, które zanieścil później w swoich Listadh, stają się bardziej czytelne, jeśli pamiętamy, że autorem ich byl czlowiek, który doświadczył tej przemiany, stając się zolnicrzem Chrystusa. Bogata synbolika uzbrojenia pomagala zresztą w konstruowaniu analogii. Przywdzianie pancerza znaczylo przeciez, nie tylko zresztą w sensie biblijnym, przywrócenic utraconej sprawiedliwości i porządku. W Liścic do Efezjan św. Pawcł ukazuje rynsztunek, jaki przywdziewa siç, aby udaremnić dzialania złych mocy, które stanowią przeszkodẹ do poznania Boga:

Obleczcie pehną zbroję Bożą, byścié mogli się ostać wobec podstępnych zakusów diabla. Nic toczymy bowiem walki przeciw krwi i ciału, lecz przeciw Zwierzchnościom, przeciw Whadzom, przeciw rządcom świata tych ciemności, przeciw pierwiastkon duchowyn zla na wyżynach niebieskich. Dlatego weźcie na sicbie pełną zbroję Boża, abyście w dzień zly zdolali się przeciwstawić i ostać, zwalczywszy wszystko (Ef $6,11-13$ ).

Dalej precyzuje poszczególne elementy rynsztunku: pancerz, pas, obuwic, tarczę, hełm oraz miecz:

Stańcie więc [do walki], przepasawszy biodra wasze prawdą i oblóktszy pancerz, którym jest sprawiedliwość, a obuwszy nogi w gotowość [głoszenia] dobrej nowiny o pokoju. W każdym polożeniu bierzcie wiarę jako tarczę, dzięki

\footnotetext{
? W 1612 roku ojciec Marian Postçkalski. bernardyn, konfraterojea Marcina, a jednocześnic de finitor z Kalwa-

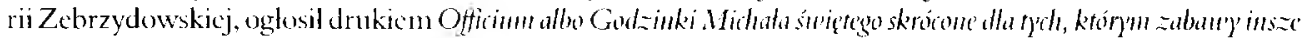

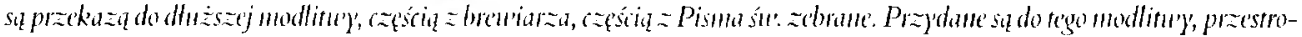
gi, odpusty bractu'u osoblin'ic stużęe (Kalwaria Zebrzydowska, 1612). To wydanic wznawiano późnicj széściokrotnic, najpic rw w roku 1618 u Franciszka Cezarcgo, któly drukowal w tym samyn czasic Żotnierskie mabo¿́nistu'o Skargi oraz Bellatorem deristiamm Bembusa. Wydawca powiçkszyl poprzednie wydanic Postękalskiego przez dodanic kilku modlitw. Chodzi tu zapewne o modlitwę „za wiçźnie”, chorych, podróżnych oraz zmarlych braci.

Cezary zadedykowal wydanie z 1618 Mikołajowi Zcbrzydowskicmu, któremu zostalo już wówczas zaledwic dwa lata życia. Zcbrzydowska stynąl z pobożności, byl zresztą zalożycielem Kalwarii Zcbrzydowskicj pod Krakowem. alc po klęsec rokoszu. w' którym wielką rolę odegrali protestanci, odsunąl siç od polityki i przed śmiercią zostal nawet tercjarzem bernardyniskim.
} 
której zdołacie zgasić wszystkie rozżarzone pociski Złego. Weźcie też lıełm zbawienia i miecz Ducha, to jest slowo Boze (Ef 6, 14-17).

Do tych motywów powróci jeszcze, pisząc do Tesaloniczan:

My zaś, którzy do dnia należymy, bądźmy trzeźwi, odziani w pancerz wiary i miłości oraz hehm nadziei zbawienia! (Tes 5, 8).

\section{Oraz w Liścic do Rzy'mian:}

Noc się posunęla, a przybliżył się dzieni. Odrzućnny więc uczynki ciemności, a przyobleczıny się w zbroję światla! (Rz 13,12).

Koncepcja walki duchowej najprościej została wylożona przez św. Pawła w zdaniu wyjętym z drugiego Listu do Koryntian:

Chociaz bowicm w cicle pozostajemy, nic prowadzimy walki wedtug ciała, gdyz oręz bojowania naszego nie jest z ciała, lecz posiada moc burzenia, dla Boga twicrdz warownych (2 Kor 10, 3-4 a).

Rynsztunek przedstawiony w Listad św. Pawla nie wyczerpuje bogatej symboliki oręża obecnego na kartach l'isma sú iętego. Wśód tego rynsztunku brakuje włóczni, która pojawia się na kartach Starego Testamenm. Slusznie wymienia ją Andreas Wang w swoim opracowaniu, ponieważ często wspomina się ją jako oręż, którym posługuje się Miles drristianus".

Dla zwykłego czlowieka rynsztunek duchowny nie był zapewne tak przemawiajacy jak w przypadku zołnierza. Żolnierz zmuszony byt prowadzić walkę „przeciw krwi i cialu” (Ef 6, 12), i dlatego starotestamentalna wizja Boga, który staje po stronie czlowieka, który walczy z nim lub za niego, była mu o wiele bliższa. W piątym rozdziale Kisę̧i Mądrości znajduje się opis, który z pewnościa przennawial do wyobraźni człowieka, oczekującego więcej od wszechmocnego Boga, niz mógl wymagać od samego siebie:

A sprawiedliwi żyją na wieki;

zaplata ich w Panu

i staranic o nich u Najwyzszego.

Dlatego otrzymaja wspaniale królestwo

i piękny diaden z rąk Pana;

ostoni ich bowien prawica,

ochraniać ich będzie ramienicm.

Jak zbroję przywdzicje swoją zapalczywość

i uzbroi stworzenie ku odparciu wrogów.

Jak pancerzem okryje siç sprawiedliwością

\footnotetext{
"Wang analizuje dokladnie poszczególne czesścu uzbrojenia. Zob. A. Wang. Der ". Mikes thristiumes" im 16. and 17.

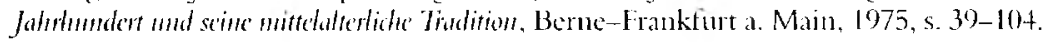


i jak przyłbicą ostoni się sądem nieobludnym.

Weźnie świętość za puklerz niezwyciężony

i jak miecz wyostrzy gniew nieubłagany,

a razem z Nim świat będzic walczyl przeciw nierozumnym.

Poleca z chmur celne pociski błyskawic.

pomkną do celu jak z dobrze napiętego luku,

a gniewne grady wyrzucone zostana jak z procy.

Wzburzą się przeciw nim wody morskie

i rzeki nicublaganic ich zatopia.

Podniesie siç przeciw nim powiew mocy

i jak wichura ich zmiecie.

Tak nieprawość spustoszy calą zicmię,

a nikczcomność obali trony możnowładców (Mdr 5, 15-23).

W starożytności przedstawiano istoty nadziemskic jako bóstwa uzbrojone, które reagıja podobnie jak ludzie, tyle tylko że ich orężem są sily natury. Stąd blyski, grzmoty, burze, światło, ciemności - wszystko to służyto za oręż w walce. Stary Testament przedstawia często Jahwe jako wojownika. Interesujące sa zwlaszcza prośby kierowane do Niego w psalmach. Jeden z nich rozpoczylla siç od slów:

Wystąp, Panie, przeciw tym, co walczą ze mną, uderz na moich napastników!

Pochwyc tarczę i puklerz

i powstań mi na pomoc.

Rzuć whócznią i toporem

na moich przéśladowców (Ps. 35, 1-3).

Nie trzeba przekonywać, że przywolane tı teksty Pisma śu'iętego stanowily bogate źródlo odniesień, zwlaszcza dla kapelanów obozowych. Wystarczylo jedynje odpowiednio uporządkować material i przystosować do potrzeb konkremego wykładu. Wyliczanie duchowego oręża oraz wyjaśnianie jego znaczeń odnosiło z pewnością duży skutek dydaktyczny. Mowa była bowiem o rzeczach zwyczajnych, bliskich żołnierzowi, zwłaszcza zaś tych, których używalo się w watce. Symbolika uzbrojenia będzie bardzo mocno związana z tą duchowością, i wszelkie pojawiające się na uzbrojeniu napisy czy wizerunki o charakterze religijnym tu będą miały swoje bezpośrednie odniesienia.

Wśród zachowanych tekstów, podejmujących zagadnienie rynsztunku duchowego, wyróżniają się dwa druki, które można przedstawić na tle polskich dzieł alegorycznych o wojnie duchowej. Są to: Stanislawa Kolakowskiego (Kulakowskiego) Wiéza Dauridon'a ze wszelkqar-

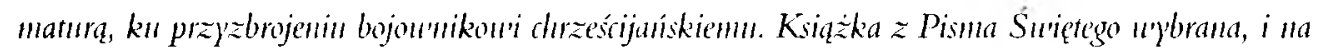
wojnę terániejsza turecką nou'o u')'dana... (bez podania roku i micjsca wydania) oraz Szymona Okolskiego Zohnierz duchou'ny' 'notad postępkn śpiegują do nieba wichodzi wydany w Krakowie

\footnotetext{
${ }^{4}$ Egzcmplarz znajdıje siç w Bibliotece Uniwersyteckicj w Warszawic sygn. 4.20.4.25.
} 
(druk. Eukasza Kupisza) w 1649 roku. Obydwa druki ukazaty się w okolicznościach związanych z wojnani, o czym autorzy mówią we wstępach, a Kolakowski zaznacza to juz nawet w samym tytule. Ten kontekst zdaje się też zawężać nieco krąg odbiorców. O ile Kolakowski wprost sugeruje przydatność swojej pracy dla wojska, Okolski starał się tu zachować pewien dystans. Treść obydwu tekstów oraz język obrazów, zrozumiały przede wszystkim dla ludzi obeznanym z rzemiostem wojennym, zdaje się jednak jednoznacznic widzieć wśród wojska pierwszy szereg odbiorców.

Dzicła Kołakowskicgo oraz Okolskicgo do dzisiaj nie znalazly wiçkszego zainteresowania wśród badaczy. Wynika to, jak siç zdaje, przede wszystkim z faktı, ze do naszych czasów dochowaly siç w dwóch praktycznic mikatowych egzemplarzach, co mogłoby wskazywać na to, że zostały „zaczytane”, i pośrednio dowodzić ich populanności. Żotnierza dudhon'nego... udało się odnaleźć zbiorach Biblioteki Sióstr Karmelitanek na Wesolej w Krakowie, a trzeba dodać, ze już Estreicher wskazywal tylko na Bibliotekę Publiczną w Petersburgu jako jedyne znane mu miejsce, w którym druk się zachowal’. Egzemplarz sióstr Karmelitanek nie został ponadto odnotowany w Centralnym Katalogu Starych Druków prowadzonym przez Bibliotekę Narodową w Warszawic, zreszta jak i cały przeclıowywany w klasz torze księgozbiór. Niewiele lepiej przedstawia siç sprawa z tekstem Kolakowskicgo, który znany jest tylko z cgzemplarza Biblioteki Uniwersyteckiej w Warszawie. Rzadkość tych tekstów oraz problem, jaki sprawia zaszeregowanic ich pod wzglçdem genologicznym, sprawiły, że Jacek Sokolski, pisząc o staropolskich poematach alegorycznych o wojnie duchowej", wnikliwie śledząc kwestie zwiazzane z duchowym ryusz tunkiem, wymienia tylko: Bermarda Kolka Vizermole duchou'nego

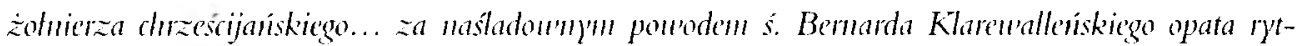

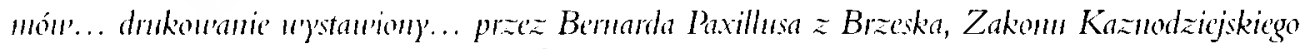
Dominikana, "'ydany' "Krakon'ie 16197, dwa pocmaty Waclawa Potockiego: Pojedynek rqerza

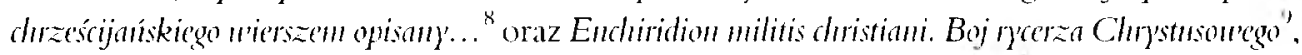

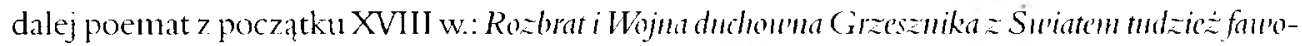

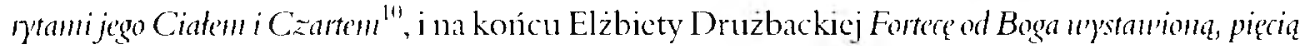
bram zamknięta, to jest: Dusza ludzka z pieciq zmystami z 1752 rokul".

Zob. K. Estreicher, Bibliografia polska, t. 23, Krakow 1910, s. 312.

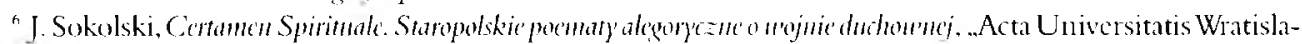

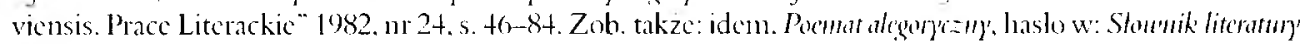
staropolskicj, red. T. Michalowska, B. Otwinowska. E. Sarnowska-Temeriusz. Wroctaw 1998, s. 682-689.

'Zdefektowany cezcomplarz (hrak zakoniczenia) znajduje siç w Bibliotece Zakladu Narodowego inn. Ossolinískich wo Wroctawiu, sygnt. XVII-2345.

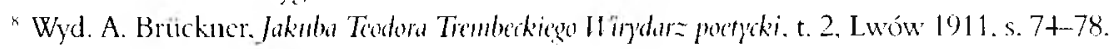

"W. Potocki, Ogrod fraszek. wyd. A. Brickner. t. 1. I.wow 1907. s. 572-581.

${ }^{10}$ Jest to zbiór utworów poetychich napisanych najprawdopodobnicj przez zakommika Zakonu Braci Muicj-

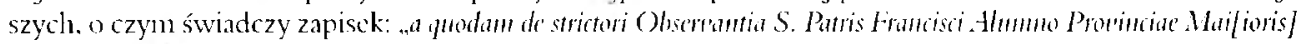
Poloniae] Reform." zannieszczony przez. Franciszka Kazanowskicgow nocie conzorskicj. Por. Sokolski. Cintamins spivituale, s. 70 .

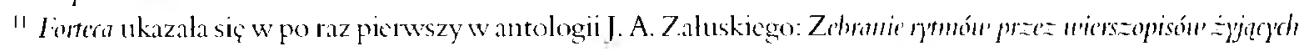

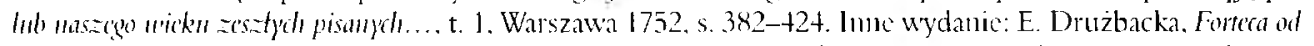

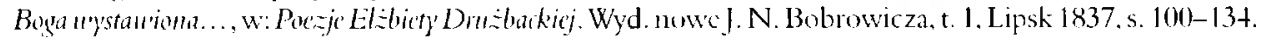


Pierwszy z tych poematów, który został później szerzej przeanalizowany w kontekście polskich przekladów I risio Filiberti, jest właściwie parafrazą lacińskicgo pierwowzoru przedstawiającego spór alegorycznych postaci Duszy i Ciala ${ }^{12}$. Ojciec Bernard swoją pracę, którą skończył w sieradzkim klasztorze dominikanów, poprzedzil obszerną „przednową o słusznej potrzebie", w której wyjaśnil ideę walkı duchowej. Takze tu pojawia się wizja wprowadzania pod sztandary ścierajacych się ze sobą armii, znane z Ću'iczeri dud wou'nych Ignacego Loyoli ${ }^{13}$ :

Gdy oni, choć są gnojkowie, Cialo i Świat, ziemscy, a diabli zaś nietoperze piekichni, marni, nikczemni, sprośni, podli, wzgardliwi, pod choragwią Lucypera przeklętego roty cielesnych namiętności, świeckich rozkoszy, szatańskich potuch, przeciwko nam kuszą się wyprawować, z nieprzestojnego występu, nie tylko walne, ale i szczególne pojedynki i zapaśne harce, z każdym z nas ważą się czynić, izali my, nieoszacowaną wedle dusz zacność mając, wszystkie dobra ziemskie i cielesne przechodzącą, pod choragwią króla nad królami Pana Chrystusa, który te wszystkie nieprzyjacioły tak mężnie zwyciężyl i sily ich wyskromil, że bez jego dopuszczenia nie tylko nas wojną pokonać, ale też i w jakimkolwick występic na nas szturmów wysadzić się niè ważą. snadnego wojowania i porządnego onych zwyciężenia omieszkamy? (k. A 3 \%. A 4).

Sam spór Duszy z Ciałem poprzedza jeszcze opisanie "rynsztunku duchownego żołnierstwa chrześcijańskiego”, w którym zıajduje się szczególowe opisanie zbroi:

Ale w jaką by zbroję oblec siç przystało?

Stusza by bulatnego kirysa się wdzialo.

Mając tez hartownego przyłbiç stalenia,

Która sprawi śmiertelnych razów oddalenia.

Więc do bystrosiecznego miecza się przypasać,

Przeciwne szturmowniki nim potężnie plaszać.

K temu jeszcze i tarczą bardzo mocną nosić,

Gdyż zaden z nieprzyjaciól niè da się wyprosić.

A nadto mieć opatrznie strawç nieprzeżytą,

Którą nocą nadarza zgoła niepożyta (k. C - D 2 i.).

Dalej następuje szczególowe wyjaśnienie, czym jest „kirysowa zbroja”. Składa się ona z czterech "sztuk”: przyznawania się z pokorą do swojej podłości, rozpoznania na każdym miejscu wszechmocności Bożej, mieć w uważaniu, „czym szkodzien, gdy niemężnym bywa w bojowaniu” oraz bycia „względu bystrego na życie świętych Bożych” (s. 3-5). W podo-

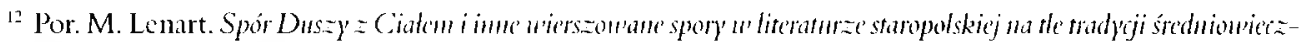
nej. Opole 20012. s. 126-138.

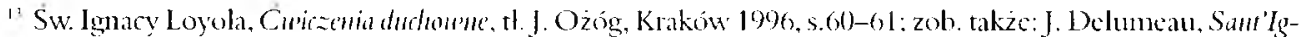
mazio, tt. 1. Zucconi, Roma-Milano 1966. 5. 62: H. Fros, Ignacy Loyold, hasto w: Encyklopedia Kardicka. t. 6. Ln-

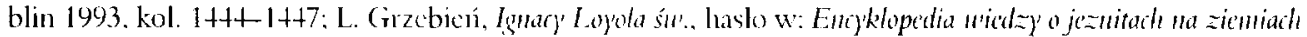
Polski i Lifu"?, 1564-1995, opr. L. Grzchicń S! przy współpracy zespolu jezuitów. Kraków 1996. kol. 2292 
bnym duchu wyjaśnia znacznic .,mocnej tarczy wiary”, „przyłbicy zbawiennej”, „obosiecznego miecza ducha". W ten sposób żohnierz jest już uzbrojony do potyczek, brakuje mu jednak jeszcze ćwiczenia:

Nie mieszkaj, byś w ten kirys stal się uzbrojony.

W którym glowy bardzo strzeż przylbice okryciem,

Bo skoro ta szwankuje, juzéś zginął z życiem.

Z mieczen się też wysadzać umiej w potykaniu.

Byś sam gardla nie stracil w ghupim przycinaniu.

Więc i tarcz ćwiczenia swego potrzebuje,

Która w szkodliwych razach zdrowie zastępuje (s. 11).

Brak tego zabezpieczenia będzie wyrzucać 1)uszy widzące swą zgubę Ciato w przedstawionym późnicj przez Kolka sporze:

Czemu na moję żądzę muńsztuka nuocnego

Nie wkladasz? Gdyż należy do rządu twego,

Abyś mnic odwodzila od grzechu wszelkiego,

Który nas zwykł nabawiać zginicnia wiecznego (k. F 4 l').

Opis „krwawego boju” zohnierza clırześcijańskiego „uzbrojonego w hartowne oręża” znajdzicmy także we wspomnianych tekstach Waclawa Potockiego. Potocki ewidentnie odnosi się do popularnych w epoce przedstawień, zapewne samego I lieronymusa Wierixa (Anvers, 1553-1619), jednego z dwóch wybitnych braci rytowników, tworzących na przelomie XVI i XVII wiekı" ${ }^{1+}$. Hienonymus Wierix na jednej ze swoich prac zatytulowanej Spirituale christiani militis cenamen przedstawia rycerza w pancerzu z mieczem i tarczą w dhoniach, depczącego alegorię Ciała, którego atakują Świat, Cirzech, Śmierć i Diabel. Cala rycina pokryta jest ponad to tekstami wyjaśniającymi sens tego alegorycznego przedstawienia, odnoszącymi się ģównie do tekstów biblijnych.

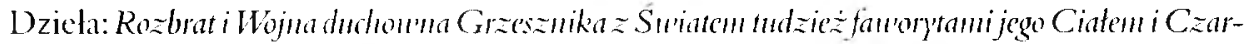
tem oraz Elżbiety Drużbackiej Forteca od Boga "'ystan'ona, choć zawierają odniesienia do zmagań wojennych, nie posiadają już opisu rynsztunku podobnego do tego, jaki dają Kolek i Potocki. Co więcej, kiedy autor Rozbratu i wojuy dudoumej opisuje .pelna zbroję Bożą”, pisze o „worze grubym” na cialo, krzyżu, który należy wziąć do ręki, a przepasać się „powrozem krętym". Podobnie jak w przypadku Potockiego odnajdujenny tu bezpośrednie odwolanie się do popularnych przedstawicú doskonalego zakonnika i doskonalej zakonnicy, którzy właśnie „uzbrojeni” są tak, jak zostako to opisane. Duży zasięg tych przedstawień zawdzięcza się rycinom, upowszechniającym ten wizerunek.

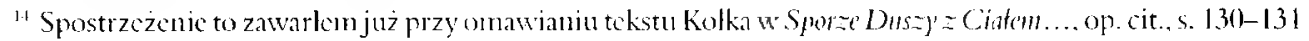
oraz ilustr. 15, na którcj zestawiono tekst Potockiego z rycin?.
} 
Tytuł wspomnianego poematu Druzbackicj wprowadza czytelnika w świat zamków, fortec, bastionów, za którymi schowany czlowiek może dać odpór przeciwnikom dusznym. W tym typie obrazowania mieści się Wieza Dau'idou'a Stanisława Kołakowskiego. Biblijne odniesienia zostaly sprecyzowane już na karcie tytułowej tego dzieła: Ksiązka z Pisma Sw wig̨tego "'ybrana, ina u'ojnęterániejszq tureckq nou'o u'ydana. Cant[icus] Canticonum 4. Sicut tumis David etc. quae aedificata cum propughaculis mille dypei pendent ex ea, et oumis armatura fortimm. Eph. 6. Przyobleczcie na sį̨ armaturę Boż, zebyście mogli dać odpór nieprzyjacielon'i u' dzien ztego, i doskonatym staną́. Sa nimi zatem: fragment z księgi Pieśni nad Pieśniami $(4,4)$ zestawiony z tekstem Listu do Efezjan $(6,10)$ św. Pawla.

Autor pozostaje postacią nieco tajemmiczą. Wedlug nicktórych badaczy byłkalwinem ${ }^{15}$, co w jakiś sposób tłumaczyłoby, niespotykane wśród pisarzy katolickich, zawężenie w wyliczaniu nieprzyjaciól, zawarte w dedykacji:

A czyż nic masz wiçkszego nicprzyjacicla nad takiego, który zabija na ciele i na duszy, jako są Turcy, Tatarzy, Saraceni, nieprzyjaciele Krzyża ś[więtego], zbojce, którzy chwałę Pana Chrystusowę i Kościoly jego obalają? (k. A 2 ı.).

Wspomniany wcześniej Kolek nie omieszkal w podobnym kontekście wymienić bardzo dokladnie nieprzyjaciól prawdziwego Kościoła, których lolacy ,jeszcze po części miçdzy sobą mają". Są to jak pisze: „heretyki, luterany, kalwiny i nowe aryjany” (k. B 2 r.). Przyklady zresztą można by tu mnożyć. l'racę swą, podpisaną w dość zagadkowy sposób pod dedykacją: „X. Stanisław Kołakowski Jacviesius P. S.” (Jaćwiezjusz), ofiarowal Janowi Karolowi Chodkiewiczowi „hr[abiemu| ze Szklowa i Myszy na Bychowie wojewodzie wileńskiemu, hetmanowi”. Dedykacja ta oraz kontekst wyprawy wojennej, która właśnie się rozpoczyna, co sugeruje zdanie:

A teraz w imię Boga najwyższego, Króla nieba i ziemie, z takąż pewną ufnością gotujesz się i wsiadasz na koni swój, zwycięzco blogosławiony na Turki i Tatary nieprzyjaciele Krzyża ś|więtegol (k. A 3 l:) -

pozwala na ustalenia co do daty powstania Wiezy Dawidonci. Chodkiewicz zmarł w obozie pod Chocimiem w 1621 roku. Ponieważ wcześniej Kołakowski wspomina o walkach ze Szwedami, wyprawie do Moskwy oraz opanowaniu księstwa siewierskiego, możemy przyjąć, że tekst powstal w czasie, gdy po klęsce pod Cecorą w 1620 roku poszukiwano hetmana, który móglby objąć dowództwo wojska przeciwko szykującej się na następny rok wojnie z Turcją (Stanisław Żólkiewski poległ w kampanii cecorskicj, a Stanisław Koniecpolski dostal się wówczas do niewoli tureckiẹ).

15 T. Z. Grabowski, Z dzicjoul liferatury kalumiskig "Polsce (1550-1650). Kraków 1906, s. 357 (Rozprawy Aka-

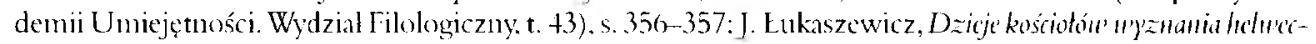

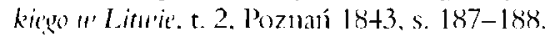


Spośród polskich bibliografów Kołakowskiego wspominany jest on nawet jako „znakomity wieku swojego poeta” przez Michała Hieronima Juszyńskiego", ,jednym z lepszych wierszopisów" nazwał go Michal Wiszniewski ${ }^{17}$. Surowy sąd o Kolakowskim wydał Tadeusz Grabowski, pisząc:

poetyckie rzemiosto nie bylo przeznaczeniem Kolakowskiego i chociaż Wiszniewski wydat się mu lepszy, zobaczylby w nim nie zdolnego, ale nudnego i daremnego wierszopisa ${ }^{14}$.

Więcej informacji o autorze dostarcza Wactaw Aleksander Maciejowski oraz Siarhiej Kawaliou" ${ }^{1 "}$.

Po krótkim tekścic skicrowanym „do laskawego czytelnika”, w którym pojawia się cytowane na różnych miejscaclı zdanie Chrystusa z Ewangelii: „beze Mnie nic nie możecie uczynić" (J 15, 5b), Kołakowski przywołuje fragment tekstu z dzicła św. Augustyna Contra quinque haereses" ${ }^{21}$, przekładając go na ośmiozgloskowiec. Przy pisaniu glównego tekstu Wieźy Dauridou'ej autor postuzył się jednak trzynastozgłoskowcem. Zaczyna od początkı, czyli, wzorem wiclu ówczesnych, od stworzenia świata. Po oczyszczeniu wodami potopu stan człowieczy prezentıje się następująco:

Skoro wyszedl z korabia Noe z synmi swemi,

Trojaki postanowił ludzki stan na ziemi.

Nabożeństwa rozkazal pilnować Semowi,

Regiment i obronę podal Japhetowi,

Aby obiema słuzyl, rozkizal Chamowi,

A we wszen by podlegat onych rozsądowi.

W tej Wiezy Dawidowej wszystko się znajduje,

Czego ku swej pomocy kazdy potrzebuje.

Naprzód jest posluszeństwo powinne Chamowe,

Jest i do rąk rycerskich oręże gotowe.

Ma i brata trzeciego na wojnę sposobna

Armate, Japhetowej snać we wszem podobna.

Co Jozue i Mojżesz w on czas pokizali,

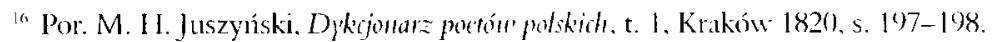

17 Por. M. Wisznicuski. Historin litcratury polskicj. t. 7. Kraków 1845. s. 130-131.

${ }^{17}$ Por. T. Z. Grabowski. op. cit., s. 357.

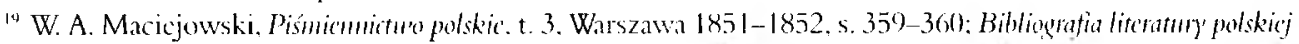

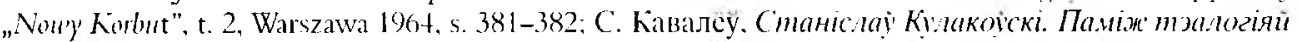

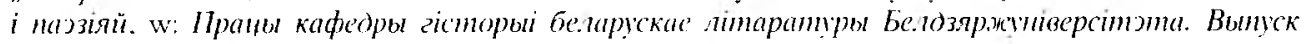
нерuts, Мinck 2001, s. 32-42.

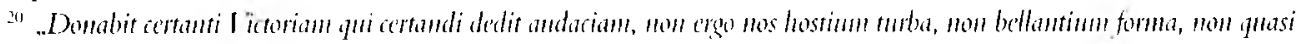

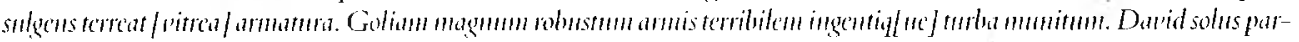

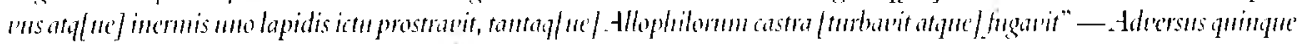
havereses (Contra quinque hacteses). Edycje: CCL 60): PL +2. W mawiasic kwadratowym zamicszczono brakujace w cytowanym teksicic slowa.
} 
Ten mieczem, ów modlitwą wojska porazali.

Gdy Mojzeszowe ręce kapłani wznosili,

Te-ż apostolskie one dwa miecze znaczyly (k. A 4).

Przytoczony fragment wystarczająco demonstruje, że mamy do czynienia z popularnymi schematani, prezentowanymi w strofach, które nie zdradzają wielkiego talentu poetyckiego. Także zestaw odwolań biblijnych, na które będzie się w calym utworze powolywal Kołakowski, nie jest ani imponujący, ani tym bardziej precyzyjny. Zdradza to albo pośpiech, albo niewielką bieglość autora, a może obydwie rzeczy naraz. Najprawdopodobniej w warunkach, w których pisal, nie mógt korzystać z żadnej konkordancji, a więc czerpal głównie z panięci i oczywiście z Biblii, którą zapewne mial pod ręką. Jeśli chodzi o fragment tekstu z dzieła św. Augustyna, który przytacza, mógł on być po prostu wynotowany wcześniej lub przepisany z jakiegoś innego źródla, gdyż należal już wówczas do znanych i cytowanych fragmentów w kontekście tematów związanych z wojną. Dalej następuje juz ,porządek Armatury Boskicj", a zatem:

Nie kierysów zlocistych, hełmów ustrojonych,

Przylbic, szyszaków i zbroi, i karacyn onych,

Pancerzów i pasów, rodel, tarcz upstrzonych,

Szabel, pałaszów, mieczów w śrzebrze uzłoconych,

Lecz armatury takiej z Wieże Dawidowej.

Użyć wedlug mądrości tu Salomonowej.

Jaką on to Armatą będąc uzbrojony,

W pokoju swe królestwo miat na wszystkie strony (k. 131 r.).

Rozpoczyna od opisu zbroi, która jest sprawiedliwość, po czym przechodzi do bardziej szczególowych elementów rynsztunku. Następna zatem jest przyłbica, która jest Jezus Chrystus „Głowy naszcj | ... J obrońca wieczna”. Tarcząjest wiara zasłaniająca ,od onych zlych postrzałów ognistych jadem napełuionych". Dalej opisuje miecz z obu stron ostry, czyli stowo Boże. Tu na końcu wywodu pojawia się charakterystyczne w dobie nie tylko wojen z poganami, ale też sporów religijnych refleksja:

Gdy takim mieczem Boskim duchownym wojujem,

Ognistych tam stów Bożych miecz przed sobą czujem.

I ręka Pańska z nami straszna przeciwnikom,

Nieprzyjacielskim niesie tam porażkę szykom (k. B 4).

Kopia, włócznia, pancerz, szabla oraz luk ze strzalami to następne części uzbrojenia, którym nadane zostało znaczenie alegoryczne w oparciu o wybrane teksty z Pisma świętego. Godna uwagi jest znajomość tekstów biblijnych i korzystanie z nich w przy opisach choćby "strzelby rozmaitej”, a to dlatego, że w czasach biblijnych bron prochowa nie byla przeciez znana. Kolakowski wydaje się przy tym obeznany z tym orężem, skoro pisze: 
Znajdą się tam muszkiety, kroski, śmigownice,

Pistoléty, pólhaki, szwedki, hakownicé,

I różne dziala owe polne i burzące,

Z ognistymi kulami prętko latające (k. C 1).

Zaledwie w dwóch miejscach autor Wiezy Dan'idon'ej posługuje się przykładami, które nie są związane z Pismentu śn'iętym. Za pierwszym razem czyni to w momencie, kiedy opisuje konia bojowego. Jest to chyba zreszta jedyny przypadek włączenia konia do rynsztunku duchownego, jaki pojawil się w literaturze tego typu. Kołakowski przytacza tu oczywiście obraz jeźdźców znany z Apokalipsy św. Jana, ale zaraz po opisie tych groźnych zwierząt o glowach podobnych lwom wyczerpała się prawdopodobnie jego erudycja w znajdywaniu biblijnych przykladów. Wspomina zatem sławnego konia „Bucifala” Aleksandra Wielkiego, a przede wszystkim wizjç świçtego Kazimierza Jaģicllończyka, który mial się ukazać z obłoków podczas bitwy. Jest to świadectwo tego, ze pamięć tego wydarzenia byla dobrze ugruntowana wśród wojska. Kołakowski bowiem nie mówi doktadnie, kiedy miało ono micjsce:

Na koniu w on czas święty Kazimierz z obłoków,

Gdy się Litwie pokazal, tam się krwie potoków

Z wielkiego wojska Moskwy jako rzeki lały,

Zaczym zwycięstwo, slawę Litwa otrzymały (k. C 2).

Jak bardzo legenda o cudownej interwencji św. Kazimierza byla zmana, niech świadczy fakt, że Skarga, pisząc żywot świętego, wspomina:

także R[oku] P[ańskicgo] 1518 swoim Polakom i Litwie w malej liczbie wojska będącym, slawne zwycięstwo zjednal na Moskwą pod Polockiem, gdzie w bialym ubiorze byl widziany [...], przeprawę przez l)źwinç rzckę i bród wojsku ukazıjący [...]. Toż samo i drugiego rokı wzywany od wojska uczynił, gdy także wielkie ufy Moskwy poważną modlitwą swoją w ręce drobnego Litewskiego podat $|\ldots|^{21}$.

Nie ma u Skargi mowy o pojawieniu się św. Kazimierza na koniu, ale to pokazuje tylko, że opowieść ta miała niejedną wersję i zapewne była ubarwiana.

Jako kolejne elementy niezbędne do wojowania wymienia Kołakowski wóz i namiot. Inwencja twórcza unusiala go jednak cliyba trochę opuszczać, skoro opisując namiot, wtrąca po raz pierwszy, i jedyny zreszta, dluzszy passus proza, w którym streszcza biblijny tekst z Ksiggi Wyjścia, zawierający słowa skierowane przez Boga do Mojzesza o misji wprowadzenia narodu wybranego do ziemi obiecancj. Trąba i choragicw zostaly opisane na końcu dzieła. Przy przedstawieniu chorągwi następuje drugi moment, w którym przywołane zostają teksty spoza Biblii. Rozwazania rozpoczyna od zacytowania pierwszych zwrotek jednego z najbardzicj

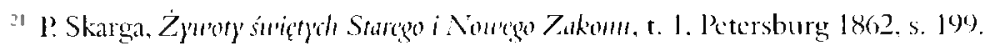


znanych hymnów liturgicznych Vexilla Regis prodetunt, którego autorem był Wenancjusz Fortunat (Valentinus Fortunatus), wiclki hymmograf z Poitiers (ok. 530 — ok. 600):

Lexilla regis prodewnt,

Fulget crucis mysterimu,

Qua vita mortem pertulit

Et morta vitan protulit ${ }^{22}$.

Przed cytowanym fragmentem znajduje siç jednak skrót: ,Theofil.", co mogtoby sugerować, ze Kołakowski za autora hymmu podaje Teofila Antiocheńskiego (zm. 182). Szczegól ten, który mógł ujść uwadze czytelnika tak w XVII wieku, jak i wspólcześnie, zastanawia jednak w kontekście podejrzeń co do sympatii z kalwinizmem. W końcu to wlaśnie Teofil Antiocheński był bodaj najczęściej przez Antytrynitarzy wspominanym autorem, ze względu na to, ze po raz pierwszy użyl po grecku slowa „Trójca” (trias) ${ }^{23}$. Można by tu zatem wyczuwać echa sporów dogmatycznych. Przywołany zaraz dalej w kontekście wizji Konstantyna, w której ukazuje mu się krzyż, Rufin to z pewnością Rufinus z Akwilei (ok. 345-410), autor licznych tłumaczeń na lacinç dzicł greckich pisarzy i teologów. Przelożył zresztą między imnymi pisma Euzebiusza, który opisuje to wydarzenie.

Refleksja nad "Chorągwią Króla niebieskiego" oraz dzialaniem chorażego Archanioła Michała, który z „anielskimi zastępami porządek uczyni na ziemi”, prowadzi do zobrazowania sądu ostatecznego.

Dzielo Kolakowskıego odnosi się wprost do postaci Dawida, która utrwalila się bodaj najbardziej w obrazie mlodzieńca zwyciężającego Goliata. Od tego też obrazu rozpoczyna zresztą autor swój poemat. Sceny z historii biblijnego króla Judy i Izraela były bardzo popularne w sztuce i literaturze. W Muzeum Miejskim w Padwie znajduje się ogrommy arras z początku XVI wicku ze sceną batalistyczną, obrazującą jeden z wielu militarnych epizodów z czasów panowania Dawida, a mianowicie historię Uriasza. To misternie tkane arcydzieło, które jest dziś ozdobą muzeum, zostalo przywiezione do Padwy z Polski być może jako część zaplaty za uczestnictwo w wyprawie wojennej dla któregoś z przedstawicieli rodziny Grompo ${ }^{24}$. Jest to też dowód na to, że w Polsce tematyka ta cjeszyła się dużym zainteresowanjem. W wyobrażeniach cnót męstwo przedstawiane by to przez postacie Dawida i Goliata ${ }^{25}$. Cnotę tę reprezen-

"Po raz pierwszy hymu byt wykonany w Poitiers 19 listopada $56{ }^{\circ}$ roku. Por. J. Julian. Dictionary of 1 y'mnoleg)'. London 1907, s. 1219-1222. 1721.

${ }_{23}$ Por. K. Górski, Bracia Polscy. hasto w: Enckklopedia Kintolicka, t. 2, Lublin 1976, kol. 1002-10015.

${ }^{27}$ Historia tego arrast1, o wymiaracl ok. 6 na 3 m.. zostah przypadkowo odkyta dziçki relacji Stanishawa Staszica. który w swoich notatkach z podrózy do Wloch. widząc arras zawicszony od wewnę̧trzncj strony fasady w Bazylice św: Antonicgo (od 1618 do 184.3). interpretowal scenç na nim przedstawiona jako odsicez wiedeńska. To spowodowalo zainteresowanic tym dzicken i w efekcle natrafienie na polską historiç arrasu. Por.

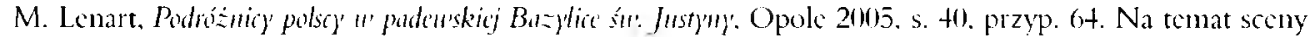
przedstawioncj na arrasic por. V. Zaranclla, Guida scomosciuta della Basilica del Samto. Quello che della Basilica del Santo nom e stato scritto. Padova 1996 , s. $+52-453$.

${ }^{2}$ Por. E. Zapolska, Choty trologulne i kundymaluce. Kraków 20010. s. 22. 178. 
tował zapewne równicz jako jedna z postaci na manierystycznym sarkofagu Stefana Batorego z 1587 roku oraz na sarkofagu Zygmunta III Wazy ${ }^{26}$.

Kolakowski w Wieży Dauvidouej zaprezentowal temat na the historii świata: od aktu stworzenia do dnia Sądı Ostatecznego. Przywolane przez niego zwroty dotyczące wojny, czy też cale wydarzenia, nie odbiegają od kanonn powszechnie znanych historii biblijnych. Ze Starego Testamentu wybiera przede wszystkim obraz warownie zbudowanej wieży Dawidowej, który pojawia się w l'eśni nad pieśniami (Pıp 4, 4). Warto zauważyć, że „wieża Dawidowa” kojarzona jest przede wszystkin z jednym z wezwań Litanii toretanskiej, która byla dobrze znana w pobożności maryjncj. Daremnic jednak moglibyśny szukać odniesienia do Maryi w calym tekście. Inne teksty starotestamentalne odwolują się przede wszystkim do bogatego repertıaru bitew, wygranych przez Naród Wybrany za sprawą Boskiej interwencji. Z Nourego Testamentu oprócz Listón' św. Pawla przytacza wypowiedź Jezusa na temat dwóch mieczy. Pośpiech byl zapewne powodem, dla którego pisząc o „zwycięstwie pod chorągwią Króla niebieskiego", powołuje siç na rozdzial 14 Eu'angedii Matcusza. O ile sam numer rozdziału mógl być jeszcze pomyłką drukarską, o tyle sam obraz Chrystusa wstającego z grobu z chorągwią w ręce należy zawdzięczać sztukom plastyczıym. Wyobraźnia zapewne okazała się w tym miejscu silniejsza od stów Pisma súciętego ${ }^{27}$.

O wiele bieglejszy i zarazem lepiej przygotowany do napisania i wyłożenia tematu wojny duchowej byl Szymon Okolski (Simon de Camenacia) zakonu św. Dominika ${ }^{28}$, autor dziela Zotnierz duchou'n' u' chotach postępkn śpiequjge do nicha u'chodzi. Ponieważ autor zyl w latach 1580-1653, pracę tẹ przyszło mu pisać w wicku prawie siedemdziesięciu lat, kiedy był już u szczytu swojej kariery w zakonie, ale też blisko kresu ziemskiego życia. Studia teologiczne odbywal we Lwowie i Bolonii. W Polsce zasłynął między innymi jako kapelan obozowy. Bral udział w wyprawach hetmana Mikotaja Potockiego w 1637 oraz 1638, które później opisal. Od roku 1641 zostal opatem klasztoru w Kanieńcu Podolskim, a następnie w 1648 zostal mianowany prowincjalem zakonu w calej Rusi. Ten niestrudzony autor prac historycznych i literackich zaslynął przede wszystkim jako twórca działa heraldycznego Orbis Polonms splendoribus caeli, triumphis mundi, pulduritudine animantium condecoratus, in quo antiqua Sarmatorum gentiliata perwetusta nobilitatis insignia etc. specificantur et relucent (t. 1-3, Kraków, 11 Franciszka Cezarego, 16+1-1643).

W literaturze naukowej dotychczas nie zajmowano się Zotnierzem duchou'nym Okolskiego ponieważ, jak już wspomniano, nic odnotowywano tego dzielka w zbiorach bibliotecznych. O znanym Estreicherowi egzemplarzu z Biblioteki Publicznej w Petersburgu nie udało siç zdobyć nowych informacji. Pisząc o Okulskim w końcu XIX wieku, Stanislaw Krzyżanowski

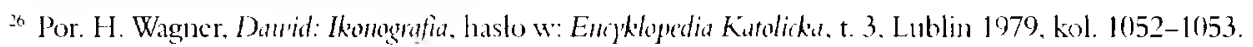

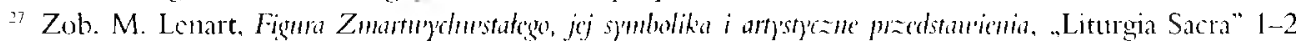
(1995), s. $142-150$.

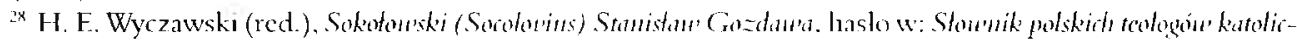
kich. t. 3, Warszawa 1983. s. 132-136. 
potrafil już podać jedynie zapisek u Maciejowskiego wraz z adnotacją, że książka ta byla w Bibliotece Zahuskich" ${ }^{2 *}$.

Okolski był osobą niezwykle szanowaną przez wojsko, któremu wicle lat służył. Jednym z tego dowodów był portret znajdujący się niegdyś w klasztorze dominikańskinn we Lwowie, który przedstawiał dominikanina z napisem u góry: „Ksiąd z Szymon Okolski”, a u dołu: „Serdeczna milość rycerstwa polskiego "31".

Swoje dzielo dedykowal „Wielmożnej Jej Mci Paniej P. Wiktoryjej z Potoka Koniecpolskiej pisarzowej polnej, koronnej, pulkownikowej wojsk J. K. M. w cnotach wspaniale kwitnącej”. Byla to córka Mikolaja Potockicgo (1595-1651) kasztelana krakowskiego i hetmana wielkiego koronnego, z którym Okolski był na wspomnianych wyprawach w 1637 oraz 1638. W dedykacji do interesującego nas tekstu nic pisze o bolesnej sprawie, jaką było wzięcie hetmana do nicwoli 26 maja 1648 roku pod Korsuniem. Wolność odzyskał dopiero w kwietniu 1650 roku. Tak więc książeczka przygotowana przez dawnego kapelana hetmańskich hufców mogla być swoistego rodzaju pociechą dla córki pozostającego w niewoli hetmana oraz zony pułkownika Koniecpolskiego pisarza polnego koronnego, uczestniczącego w wyprawie przeciw Chmielnickiemu. Zwracając się do czytclnika, pisze o bolesnych wydarzeniach ostatniego roku:

Na wygnaniu teraz, przez swawolne i królom swym, i przysięgom wiary niechowające chłopstwo i kozactwo ukarane będą. Nie mam konsolacyjej innej po zabitych okrutnie braciej mojej, po zniesieniu klasz torów dwudziestu kilku, po spustoszeniu ołtarzów, obrazów, po pobraniu kieliclıów, krzyźow, ornatów, po zepsowaniu krzyśnic [chodzi o chrzcielnice-M. L.], po podeptaniu i obelżeniu Sakramentu Przenajświętszego, tylko się udać do Boga, do bogomyślności, do rozınyślania.

Okolski postanowil zatem w tych trudnych czasach wydać książeczkę „grubym piórem” pisaną, w której opisuje żołnierstwo duchowe, pozostawiając innym ,polityczne i prawdziwe wierne”. Wszystko po to, aby zachęcić „do wojny duchowej z światem, z ciałem i z szatanem przeklętym". Całość pracy ojca Szymona jest ułożona na sposób katechizmowy w pytaniach i odpowiedziach. Rozpoczyna się pytaniem: „Co jest żołnierz duchowny?”. „Ten jest — pada odpowiedź - zwycięzca ciala, świata i czarta”. Na pytanie „czym ich zwycięża?” następuje odpowiedz:

Mieczem wiary Chrystusowej. Zbroją milości Boga i bliźniego. Pancerzem nadzieje z nieba. Czysakiem [szyszakiem - M. L.] głowy Kościoła ś[więtego].

\footnotetext{
29 W. A. Maciejowski. op. cit., s. 806 . Por. S. Krzyżanowski. De Simnis Okolscii monachi ordini Sancto Donninico

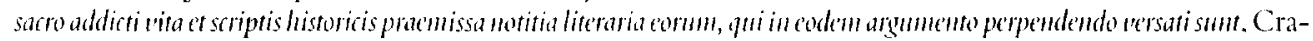
coviac 1870 .

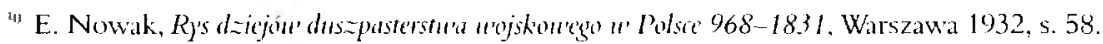


Dalej następuja pytania dotyczące wodzów w tej wojnic. I tak hetmanem jest Bóg Ojciec, drugim Jezus Chrystus, a trzecim Duch Świçty. Oboźnym - św. Marcin, bo „wygadza stanowiskiem każdym”; strażnikami są: św. Michal. bo „straż przeciw Lucyterowi odprawowal”. natomiast podstrażnikiem św. Bazyli, .który zabil Juliana Apostatę”. Każdy aniol jest pisarzem, ponieważ spisuje sprawy i odıosi je do Boga. Pułkowników jest wielu. Na początku wymienia Okolski św. Piotra, dalej Szczepana, który prowadzi putk męczenników; św. Jana Chrzciciela, w którym to pułku są wyznawcy i święci. Kolejny, czwarty pulk, którego szczególną obroíczynia jest Matka Boża, prowadzi św. Urszula. Dalej jest

pulk starodawny [...] patriarchów dawnych, Abrahana. Izaaka i Jakuba, których pokolenia oświecone na duszy staly się przysposobieni do wiktoryjej ciała, świata i szatana przcklętego.

Po nim następuje jeszcze pułk proroków. Rotmistrzani sa: Job, drugim jest św. Paweł, a trzecim Krzyż święty. Ta niespotykana rola krzyża znajduje wythumaczenie, które warto zacytować, ponieważ przechodzi w wyklad na temat bieżących wydarzeń:

Na trzecim miejscu kladę Krzyź święty, bo dopiero po śmierci Pana Chrystusowej Paweł św. nam ten krzyz święty rozgłosił i do wiadomości podał, mówiąc. .My opowiadany Clırystusa ukrzyzowanego, który jest zgorszeniem u Zydów, głupstwem u niewiernych narodów, ale u ludzi imieniem Chrystusowym napiętnowanych jest Krzyż św. mocą i potẹgą Boską, i mądrością niebieską". Za tym Rotmistrzem otrzymał zwycięstwo Konstantyn Wielki cesarz, gdy przy Krzyżu świętym obaczył na niebie i przeczytat: "Pod tym znakiem zwyciężysz, w tym znaku nieprzyjaciela zniesiesz". Za tym Rotmistrzem zwyciężyl i król polski Jagicłlo, gdy Krzyżacy, naśmiewając się, dwa nutu miecze przyslali: a on na ten czas pod opiekę Krzyża świętego przy najświętszej ofierze poddawał się i wojsko swoje. Za tym Rotmistrzen zwyciężył król Stefan, gdy po walnej potrzebie pod Gdańskiem heretyków diabelskicj ręki Krzyż święty wystawil i napisat: „Nie nam, ale tobie Panie niech będzie z tego chwała na wicki”. A żaden nieprzyjaciela swego nie zwycięzy, kto pod tym Rotmistrzem nie wojuje. Rzeczesz: A czemuż nas Tatarowie niechrzestowie wojują? Odpowiem: Stali się na nas biczem Bożym, i nie oni, ale Bóg nas bije. Przeto chceszli, abyś Tatarów zwyciężal, słuchaj rady świętego męczennika i biskupa Nila. I is hostem exammare, pecata exarma. Mówi: „Chcesz szable wydrzeć nieprzyjacielowi i zbroje? Zlóż zbroje grzechów i broń szatańską od siebie odrzuć". Mówisz: Ale siç juz i spowiadany? - A dosyćuczynienie gdzie? A wracanie się do złych nalogów kiedy? A otarcie lez z oczu ubogich, którzy na cię dla złupiennia przed Bogicm płaczą, gdzie podziejesz? Wszytkic te rzeczy są u Boga obecne, jego oszukać taką spowiedzią nie możesz, ale siebie.

Dalszymi rotmistrzami są aniolowic. Tiı obeznany z wojskowym porządkiem Okolski wprowadza rozróżnienic, które jest ważne, ponieważ anioł stróż porucznika to nie to samo co 
rotmistrza, a spory rozstrzyga anioł Królestwa. Rotmistrzami są też patronowie, „których sobie obierają królestwa i miasta". Do przyjaciól naszkicowanego w ten sposób obozu zalicza Chrystusa, Maryję, Trójcę Przenajświętszą, Aniolów oraz wybranych świętych.

Teraz następuje przedstawienie dobrego zołnierza. Najpierw wymienia Okolski te przymioty, po których można go poznać. Ialej charakteryzuje jego znak, którym jest „zazdrość dobra”, oraz wskazuje, jak nale ży „stawać przeciwko nieprzyjaciolom”. Tutaj wymienia: animusz, siły, pracę, czułość | czujność - M. L. | i poshuszeństwo, przy czym zwraca uwagę zwłaszcza na ostatnią cechę, którą powinien charakteryzować się żołnierz, słuchając przelożonych, nawet jeśli nic są dobrzy. Dalej następują rozważania na temat honoru oraz nagród, jakie przysługują zolnierzowi duchowemu. Wodpowiedziach na kolejne pytania Okolski uczy, jak szturmować przeciw ciałı, światu oraz szatanowi, w których to pouczeniach dominują obrazy potwierdzające biegłą znajomość rzemiosła wojennego przez autora. I tak na przykład kto szturmuje przeciw cialu,

ostroznie i cicho to czyni. Kopie miny pod ziemia i zaklada prochy, albo przechodzi tymi potajnikami do obozu nieprzyjacielskiego i zalewa dziala, moczy proclıy, ognie zaklada, hetmany zabija i turbuje wojska. Kto też szturmować clice przeciw ciału, nie potrzeba trąbić w szklenice, bębnić w półmiski, wykrzykać w swary niewiéscich glosów, ale trzeba cicho kopać w sobie doły pokory, lochy sądy Boskiego, zakładać ognie Boskiej miłości, armatę ciala niszczyć i prochy pożądliwości gasić, okazje jako pobudki ku złemu wykorzeniać, turbować cialo, nie dawać rozkoszy, nie chicié dać gospody Wenerze córce Bachusowi.

W tych działaniach zbrojnych potrzebne jest znaczne zaopatrzenie wojskowe, i stąd następuje teraz opisanie kolejnych elementów, które przydają się do prowadzenia wojny. Najpierw Okolski opisuje "municyję" przeciw ciału, światu i szatanowi. Dalej przechodzi do umocnień. Najpierw strażnic: wstydu, bojaźni Boskicj, czułości oraz miłości Boga i bliźniego, a następnic ,przywatków” duchowych, przechodząc w końcu do „municyjej duchownej”. Dwie bramy budynku duchownego, które bywają przy fortecach, są kolejnym przedmiotem rozważań. Do odporu nieprzyjaciela potrzeba strzelb duchownych, których doświadczony kapelan obozowy wymienia cztery. Ostatnią jest modlitwa, której formulę przytacza autor. Są to akty strzeliste o Męce Chrystusa, przedzielone modlitwą "Ojcze nasz" i "Zdrowaś Maryja”. Po tym następuje zakończenie oraz wskazania różnych form nabożenstw do Maryi, powszechnie wówczas znanych (litania, modlitwa O Maryja Bogurodzico..., akty oddania się na wieczną stużbę oraz na wiecznego niewolnika Maryi).

Okolski w swoim Zotnierzu duchon'ny'm ani razu nie podaje źródel przykładów, którymi ihustruje kolejne elementy wojennych rynsztunków. Dzięki temu wytrawny kaznodzicja obozowy opracowal temat, poslugując się zapewne najbardziej znanymi w swoich czasach odniesieniami. I Iistorie cytowane z pamięci powodıją, że tckst przeradza się czasem w rodzaj krótkiego kazania. Jednym z motywów częściej przywoływanych jest przyjmowana ze spokojem śmierć. I tak oto: król Nawarry I Ienryk kizze sobie przed śmiercia przynieść trupia glowę, 
na której pisze, że nigdy siç jej nie bał; hetman Epanninond odejmuje ręce od ran, aby krew mogla swobodnie wypłynąć z ciala; Piotr męczennik z zakonu św. Dominika wyciekającą 7. ran krwią pisze na ziemi wyznanie wiary: św. Cyprian placi pieniądze wlasnemu katowi. Na szczególnz̧ uwage zasługıje odwoływanie siç do idei Militia caelestis. Trudno powiedzié, czy Okolski, który studiował we Whoszech, kojarzył to z poczytnym dzicłkiem Jerónimo San Pedro (występuje na drukach także jako: I Tieronimo S. Pietro lub Hieronyno san Pictro), spod którego pióra wyszedl traktat Militia celeste" ${ }^{3 t}$. Tłumaczenie na jezyk włoski ukazało się w 1584 rokut?

Kontekst Rusi każe zwrócić uwage jeszcze na jedną rzecz. Otóż obok św. Michala Archanioła pojawia się w tekście Okolskiego św. Bazyli jako pogromca cesarza Juliana Apostaty. Dowodzi to, że historia o tym wydarzeniu, które przytacza zresztą sam Skarga, byla powszechnic znana i nie zaslugiwala nawet na dokładniejsze wyjaśnienie. Mowa tu o modlitwie sw. Bazylego przed obrazem matki Bożej, na którym byl tez przedstawiony św. Merkuriusz żołnierz i męczennik z włócznią. Bazyli modlił się do Boga, aby wyzwolił Kościól od ręki prześladowcy Juliusza. W pewnym momencie obraz zaćmił się, i po clıwili św. Merkuriusz ukazał się z zakrwawioną wócznią. Po tym wydarzeniun okazalo się, ze cesarz zginąh na wojnie w Persji. ${ }^{3,3}$.

Prosty język wykładu oraz konkretne przyklady postępowań, aktów strzelistych, modlitw, jakie proponuje prowincjal Rusi, byly niewątpliwie zaletą tego dzielka. Wydaje się, ze pisząc o wojnie duchowej, ojciec Szymon nie mógt nie mié przed oczyma zastępów wojska, z którym tak bardzo byl zwiazany, choć w zalożeniu przekazuje tekst szerokiemu gronu odbiorców. „Grube pióro” Okolskiego musiato przysporzyć tekstowi sporej popularności. Opisane przez niego umocnienia bronionej twierdzy doskonale pasowaly do sytuacji spod Zbaraza.

I jeszcze jedna uwaga. Jeżeli gdzieś należałoby szukać genezy tytułów tak pomystowych

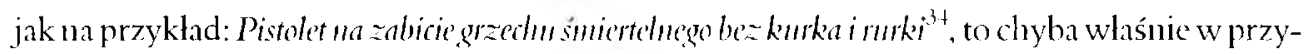
wolanych tu tekstach albo im podobnych ${ }^{35}$.

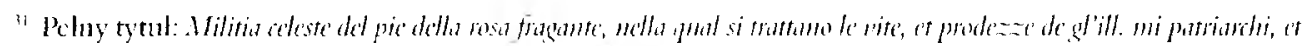

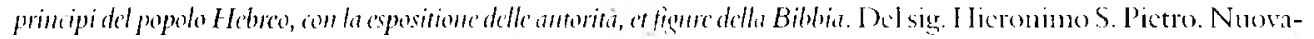
mente tradotta dalla lingua spagnuola dal signor Alfonso de Ulloa. in Venetia appresso gli lecredi di Marchio Sessa. $158+$.

Znany mi egzemplarz został wydany w Wenceji w I6177 (Biblioteka Watykańska sygn.: B. Vat. Rac. (icr. Teologia V. 15+5). We W/oszech zachowalo siç do dziśokolo dzie siçciu cgzenuplarzy tego tekstu z różnycla wydań.

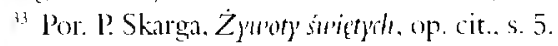

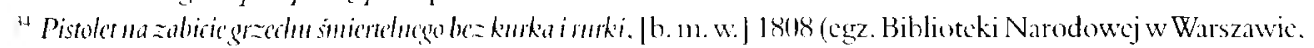
sygn. I 2.048 .455$)$.

${ }_{13}^{3}$ Trudno powic dzić, czy do ponyzzzych tekstów zaliczalo siç w jakiś sposcíb dziclko Stanishawa Radzixilla

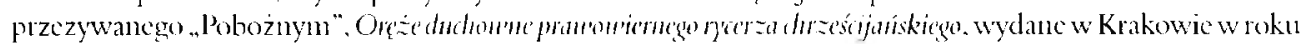
1591, które niestety nic dochowato siç do naszych czasów: Estrcicher pisze: . Rzecz jest o znajomósi Bozecj. o sakranuentach, o oficrze mszy. o usprawiedliwicniu. o grzech ı, o odpustach, o dniu sądnym, o Mesjaszı. Kończy o skutkach rozmyślania”. Najuyraźnicj jednak hibliograf mial te informacje z drugicj ręki. skoro nic porratil podać micjsca, w którym druk siç znajduje. dedając jedynic uwagç: . Mial przed 30 laty Gicjsztor" (zob. K. Estrcicher. Bibliografia polska. t. 26. Krakiów 1915. s. 95). 